Volume. 2 Nomor. 2

Periode: Juli - Desember 2018; hal. 92-99

p-ISSN : 2580-1112; e-ISSN : 2655-6669

Copyrighr@2018

Jurnal Ilmiah Keperawatan

Penulis memiliki hak cipta atas artikel ini Orthopedi (JIKO)

journal homepage:

https://ejournal.akperfatmawati.ac.id

\title{
Efektivitas Penyuluhan Kesehatan Reproduksi Terhadap Pengetahuan Dan Sikap Remaja
}

\author{
Siti Utami Dewi ${ }^{1}$ \\ Akademi Keperawatan Fatmawati
}

\begin{abstract}
Abstrak
Masa remaja adalah masa yang dianggap rawan dalam kehidupan karena merupakan masa peralihan dari kehidupan anak menjadi kehidupan dewasa yang penuh gejolak. Menjadi remaja berarti menjalani proses berat yang membutuhkan banyak penyesuaian, lonjakan pertumbuhan badan dan pematangan organ-organ reproduksi adalah salah satu masalah besar yang mereka hadapi, tidak terkecuali organ reproduksi yang rentan terhadap infeksi saluran reproduksi, kehamilan, penyakit menular seksual, dan penggunaan obat-obatan terlarang. Penelitian ini bertujuan untuk mengetahui Efektivitas penyuluhan kesehatan reproduksi tentang seksual pranikah terhadap pengetahuan dan sikap remaja. Penelitian ini menggunakan jenis penelitian intervensi dengan menggunakan rancangan one group pretest-postest design, yaitu meneliti hubungan sebab akibat dalam kelompok intervensi tanpa menggunakan pembanding kelompok kontrol. Hasil penelitian ini menunjukan adanya efektivitas penyuluhan kesehatan reproduksi tentang seksual pranikah terhadap pengetahuan dan sikap remaja. Hasil uji statistik paired t-test diketahui nilai $\mathrm{P}=0,000$, artinya penyuluhan kesehatan reproduksi tentang seskual pranikah efektif secara sangat signifikan terhadap pengetahuan dan sikap remaja.
\end{abstract}

Kata Kunci: Efektivitas, Penyuluhan Kesehatan Reproduksi, Pengetahuan, Sikap

\section{Abstract}

Adolescence is a time that is considered vulnerable in life because it is a period of transition from a child's life to a tumultuous adult life. Being a teenager means undergoing a heavy process that requires a lot of adjustments, a surge in body growth and maturation of reproductive organs is one of the big problems they face, including reproductive organs that are vulnerable to reproductive tract infections, pregnancy, sexually transmitted diseases, and drug use - illegal drugs. This study aims to determine the effectiveness of reproductive health counseling about premarital sex on the knowledge and attitudes of adolescents. This study used a type of intervention research using the design of one group pretest-posttest design, which examined the causal relationship in the intervention group without using a control group comparison. The results of this study indicate the effectiveness of reproductive health counseling on

1 e-mail: utamidewi1701@gmail.com 
premarital sex toward adolescent knowledge and attitudes. The results of the paired ttest statistical test revealed the value of $P=0,000$, meaning that reproductive health counseling about premarital sex is very significantly effective on adolescent knowledge and attitudes.

Keywords: Effectiveness, Reproductive Health Education, Knowledge, Attitude

\section{Pendahuluan}

Sebagian besar populasi dunia lebih dari 1,75 miliar berusia antara 10 sampai 24 tahun (WHO, 2008). Satu dari setiap lima orang di dunia adalah remaja, dan $85 \%$ dari mereka tinggal di negara berkembang (WHO, 2008).

Proyeksi penduduk remaja Indonesia tahun 2000-2025 oleh Bappenas umur 10- 24 mencapai 64 juta pada tahun 2007 atau 28,6\% dari jumlah penduduk Indonesia sebanyak 222 juta. Masa remaja dibagi menjadi tiga periode yang terdiri dari: masa remaja awal usia 10-14 tahun, masa remaja pertengahan usia 15-16 tahun, dan masa remaja akhir usia 17-19 tahun. (Depkes, 2004)

Masa remaja adalah masa yang dianggap rawan dalam kehidupan karena merupakan masa peralihan dari kehidupan anak menjadi kehidupan dewasa yang penuh gejolak. Menjadi remaja berarti menjalani proses berat yang membutuhkan banyak penyesuaian, lonjakan pertumbuhan badan dan pematangan organ-organ reproduksi adalah salah satu masalah besar yang mereka hadapi, tidak terkecuali organ reproduksi yang rentan terhadap infeksi saluran reproduksi, kehamilan, penyakit menular seksual, dan penggunaan obatobatan terlarang. Perasaan seksual yang menguat tak bisa tidak dialami oleh setiap remaja meskipun kadarnya berbeda satu dengan yang lain. Begitu juga kemampuan untuk mengendalikannya. (Sarwono, 2007)

Beberapa waktu yang lalu masalah remaja dengan alat reproduksinya kurang mendapat perhatian karena umur relatif muda, masih dalam status pendidikan sehingga seolah-olah bebas dari kemungkinan menghadapi penyulit dan penyakit yang berkaitan dengan alat reproduksinya. Terbukti bahwa remaja yang sedang mencari identitas diri telah sangat mudah menerima informasi dunia berkaitan dengan masalah fungsi alat reproduksinya sehingga cenderung menjurus kearah pelaksanaan hubungan seksual yang semakin bebas.

Penelitian menunjukan bahwa kejadian semakin bebasnya hubungan seksual, seolah-olah mencoreng muka pendidik, orang tua, dan masyarakat sehingga menimbulkan kesadaran yang agak terlambat. Penelitian di Jakarta, Yogyakarta, dan bahkan Denpasar menunjukan bukti bahwa dikalangan remaja telah terjadi revolusi dalam hubungan seksual menuju kearah liberalisasi tanpa batas. (Manuaba, 2005).

\section{Metode Penelitian}

Desain yang digunakan dalam penelitian ini adalah one group pretestpostest design. Dimana dalam penelitian ini peneliti melakuakan observasi pertama (pretes) yang memungkinkan peneliti dapat menguji perubahan-perubahan yang terjadi setelah adanya eksperimen (perlakuan).

Teknik pengambilan sampel dalam penelitian ini adalah dengan menggunakan Purposive Sampling dengan jumlah sampel 36 responden. Tempat diadakan penelitian ini di Gunung Mujil Kelurahan Bumurejo Kebumen. Penelitian dilakukan pada bulan Maret hingga Mei 2010.

\section{Hasil Penelitian}

Karakteristik responden berdasarkan usia 


\begin{tabular}{|c|c|c|}
\hline Usia & Frekwensi & $\%$ \\
\hline 14-15 tahun & 9 & 25 \\
\hline 16-18 tahun & 15 & 41,67 \\
\hline 19-24 tahun & 12 & 33,33 \\
\hline Total & 36 & 100 \\
\hline
\end{tabular}

Tabel 1. Menunjukkan usia yang paling banyak dalam penelitian ini yang menjadi responden yaitu usia antara 16-18 tahun sebesar $41,67 \%$ yang merupakan usia remaja pertengahan, dan paling

Tabel 2. Distribusi Frekwensi Berdasarkan Jenis Kelamin

\begin{tabular}{lcc}
\hline Jenis Kelamin & Frekwensi & $\%$ \\
\hline Laki-laki & 15 & 41,67 \\
Perempuan & 21 & 58,33 \\
\hline Total & 36 & 100 \\
\hline
\end{tabular}

Tabel 2. Menunjukkan karakteristik responden berdasarkan jenis kelamin, bahwa responden perempuanlah yang paling banyak menjadi responden rendah pada usia 14-15 tahun sebesar $25 \%$.

Karakteristik responden berdasarkan jenis kelamin

Tabel 3. Distribusi Frekwensi Berdasarkan Tingkat Pendidikan

\begin{tabular}{lcc}
\hline Tingat Pendidikan & Frekwensi & $\%$ \\
\hline SD & 0 & 0 \\
SLTP & 8 & 22,22 \\
SLTA/SMK/STM & 27 & 75 \\
PT & 1 & 2,78 \\
\hline Total & 36 & 100 \\
\hline
\end{tabular}

Tabel 3. Menunjukkan karakteristik responden berdasarkan tingkat pendidikan, yang paling banyak menjadi responden dalam penelitian ini yaitu pada tingkat pendidikan SMA atau sederajatnya sebesar $75 \%$ dan paling

sebesar 58,33\%, dibandingkan dengan responden laki-laki sebesar 41,67\%.

Karakteristik responden berdasarkan tingkat pendidikan

Tabel 4. Distribusi Frekwensi Responden yang Pernah Mendapatkan Informasi tentang

Pendidikan Reproduksi

\begin{tabular}{lcc}
\hline Responden yang mendapatkan informasi & Frekwensi & $\%$ \\
\hline Pernah & 31 & 86,11 \\
Tidak & 5 & 13,89 \\
\hline Total & 36 & 100 \\
\hline
\end{tabular}

Tabel 4. Menunjukkan bahwa jumlah responden yang pernah mendapatkan informasi tentang pendidikan reproduksi yang diterima responden sebelumnya sebanyak 31 orang rendah pada pendidikan tingkat PT (perguruan tinggi) sebesar 2,78\%.

Responden yang pernah mendapatkan informasi tentang pendidikan reproduksi

$(86,11 \%)$, dan jumlah responden yang tidak pernah mendapatkan informasi tentang pendidikan seksual sebanyak 5 orang $(13,89 \%)$.

Tingkat Pengetahuan Responden 
Tabel 5. Tingkat Pengetahuan Responden Pretes-Postes

\begin{tabular}{clcccc}
\hline \multirow{2}{*}{ No } & \multirow{2}{*}{ Kriteria skor } & \multicolumn{2}{c}{ Pretes $(\mathrm{O} 1)$} & \multicolumn{2}{c}{ Postes $(\mathrm{O} 2)$} \\
\cline { 3 - 6 } & & $\mathrm{f}$ & $\%$ & $\mathrm{f}$ & $\%$ \\
\hline 1 & Tinggi $(76-100 \%)$ & 14 & 38,89 & 32 & 88,89 \\
2 & Sedang $(56-75 \%)$ & 19 & 52,78 & 4 & 11,11 \\
3 & Rendah $(<56 \%)$ & 3 & 8,33 & 0 & 0 \\
\hline & Total & 36 & 100 & 36 & 100 \\
\hline
\end{tabular}

Tabel 5. Menunjukkan bahwa sebelum diberikan penyuluhan kesehatan reproduksi sebagian kelompok responden mempunyai pengetahuan sedang tentang pendidikan seksual pranikah sebesar 19 orang $(52,78 \%)$, responden yang mempunyai pengetahuan tinggi sebanyak 14 orang $(38,89 \%)$, dan yang mempunyai pengetahuan rendah sebanyak 3 orang $(8,33 \%)$.

Kemudian jika dibandingkan dengan hasil skor pengetahuan responden

Tabel 6. Sikap Responden Tentang Seksual Pranikah Pretes-Postes

\begin{tabular}{clcccc}
\hline \multirow{2}{*}{ No } & \multirow{2}{*}{ Kriteria skor } & \multicolumn{2}{c}{ Pretes $(\mathrm{O} 1)$} & \multicolumn{2}{c}{ Postes $(\mathrm{O} 2)$} \\
\cline { 3 - 6 } & & $\mathrm{f}$ & $\%$ & $\mathrm{f}$ & $\%$ \\
\hline 1 & Baik & 19 & 52,78 & 30 & 83,33 \\
2 & Cukup baik & 17 & 47,22 & 6 & 16,67 \\
3 & Kurang baik & 0 & 0 & 0 & 0 \\
\hline & Total & 36 & 100 & 36 & 100 \\
\hline
\end{tabular}

Tabel 6. Menunjukkan bahwa sikap responden tentang seksual pranikah sebelum pemberian penyuluhan kesehatan reproduksi adalah sebanyak 19 orang $(52,78 \%)$ baik, 17 orang $(47,22 \%)$ cukup baik, dan tidak ada responden yang memiliki sikap kurang baik. Kemudian setelah pemberian penyuluhan kesehatan

\section{Sikap Responden} terhadap seksual pranikah. setelah diberikan penyuluhan kesehatan reproduksi maka tingkat pengetahuan responden tentang pendidikan seksual pranikah mengalami peningkatan ini dapat dilihat bahwa responden yang mempunyai pengetahuan tinggi setelah diberi penyuluhan kesehatan reproduksi sebanyak 32 orang $(88,89 \%), 4$ orang responden yang mempunyai pengetahuan sedang $(11,11 \%)$, dan tidak ada responden yang mempunyai pengetahuan rendah.

reproduksi jumlah sikap responden yang baik tentang seksual pranikah mengalami peningkatan yaitu sebanyak 30 orang $(83,33 \%)$, jumlah sikap cukup baik sebanyak 6 orang $(16,67 \%)$ dan begitu juga pada saat postes tidak ada responden yang mempunyai sikap kurang baik

Tabel 7. Hasil Paired Samples Test Tingkat Pengetahuan

\section{Paired Differences}

\begin{tabular}{|c|c|c|c|c|c|c|c|c|}
\hline & \multirow[t]{2}{*}{ Mean } & \multirow[t]{2}{*}{$\begin{array}{c}\text { Std } \\
\text { Deviation }\end{array}$} & \multirow[t]{2}{*}{$\begin{array}{l}\text { Std. } \\
\text { Error } \\
\text { Mean }\end{array}$} & \multicolumn{2}{|c|}{$\begin{array}{l}\text { 95\% Confidence } \\
\text { Interval of the } \\
\text { Difference }\end{array}$} & \multirow[t]{2}{*}{$\mathrm{t}$} & \multirow[t]{2}{*}{ df } & \multirow[t]{2}{*}{$\begin{array}{l}\text { Sig. (2- } \\
\text { tailed) }\end{array}$} \\
\hline & & & & Lower & Upper & & & \\
\hline $\begin{array}{l}\text { Pair } 1 \text { PRETES - } \\
\text { POSTEST }\end{array}$ & -3.72 & 1.137 & .189 & -4.11 & -3.34 & -19.648 & 35 & .000 \\
\hline
\end{tabular}

Pada Tabel 7. Didapatkan data yaitu mempunyai perbedaan tingkat pengetahuan antara sebelum dan sesudah penyuluhan, terjadi peningkatan pengetahuan setelah diberikan penyuluhan. Hasil uji statistik Paired $t$ - test diketahui nilai $\mathrm{T}_{\text {hitung didapatkan }}$ -19,648 menunjukkan bahwa tingkat pengetahuan sebelum diberikan penyuluhan lebih kecil dari pada sesudah pemberian penyuluhan. 
Tabel 8. Hasil Paired Samples Test Sikap

\begin{tabular}{|c|c|c|c|c|c|c|c|c|}
\hline & \multicolumn{5}{|c|}{ Paired Differences } & \multirow{3}{*}{$\mathrm{t}$} & \multirow{3}{*}{$\mathrm{df}$} & \multirow{3}{*}{$\begin{array}{l}\text { Sig. (2- } \\
\text { tailed) }\end{array}$} \\
\hline & \multirow[t]{2}{*}{ Mean } & \multirow[t]{2}{*}{$\begin{array}{c}\text { Std } \\
\text { Deviation }\end{array}$} & \multirow{2}{*}{$\begin{array}{l}\text { Std. } \\
\text { Error } \\
\text { Mean }\end{array}$} & \multicolumn{2}{|c|}{$\begin{array}{l}95 \% \text { Confidence } \\
\text { Interval of the } \\
\text { Difference }\end{array}$} & & & \\
\hline & & & & Lower & Upper & & & \\
\hline $\begin{array}{l}\text { Pair } 1 \text { PRETES - } \\
\text { POSTEST }\end{array}$ & -10.78 & 6.762 & 1.127 & -13.07 & -8.49 & -9.564 & 35 & .000 \\
\hline
\end{tabular}

Tabel 8. Didapatkan data yaitu mempunyai perbedaan sikap responden antara sebelum dan sesudah pemberian penyuluhan, terjadi peningkatan sikap setelah diberikan penyuluhan. Hasil $\mathrm{T}_{\text {hitung }}$ didapatkan $-9,564$ menunjukkan bahwa sikap responden sebelum diberikan penyuluhan lebih kecil dari pada sesudah pemberian penyuluhan.

\section{Pembahasan}

Dari hasil penelitian yang didapatkan berdasarkan pertanyaan yang diajukan melalui kuesioner kepada 36 orang responden, karakteristik responden meliputi usia, jenis kelamin, tingkat pendidikan dan jumlah responden yang pernah mendapatkan informasi tentang pendidikan seksual yang diterima sebelumnya. Tabel 1. Menunjukkan usia yang paling banyak dalam penelitian ini yang menjadi responden yaitu usia antara 16-18 tahun sebesar $41,67 \%$ yang merupakan usia remaja pertengahan, dan paling rendah pada usia 14-15 tahun sebesar 25\%, hal ini dikarenakan jumlah remaja di Gunung Mujil pada usia 16-18 tahun merupakan kelompok remaja terbanyak, mudah untuk ditemui dan dijumpai, selain itu pada usia tersebut timbul gejala bangkitnya dorongan seksual (Sarwono, 2007), sehingga menyebabkan remaja tertarik dan antusias terhadap materi yang diberikan oleh peneliti, karena rasa keingintahuan remaja pada usia tersebut sangat besar, mengenai kesehatan reproduksi tentang seksual pranikah.

$$
\text { Tabel 2. Menunjukkan }
$$
karakteristik responden berdasarkan jenis kelamin, bahwa responden perempuan yang paling banyak menjadi responden sebesar 58,33\%, dibandingkan dengan responden laki-laki sebesar 41,67\%. Dikarenakan jumlah remaja perempuan di Gunung Mujil merupakan kelompok remaja terbanyak.

Tabel 3. Menunjukkan karakteristik responden berdasarkan tingkat pendidikan, yang paling banyak menjadi responden dalam penelitian ini yaitu pada tingkat pendidikan SMA atau sederajatnya sebesar $75 \%$ dan paling rendah pada pendidikan tingkat PT (perguruan tinggi) sebesar $2,78 \%$, hal ini dikarenakan remaja di Gunung Mujil setelah lulus SMA atau sederajatnya lebih memilih untuk bekerja ketimbang untuk kuliah, selain itu juga dikarenakan dari faktor ekonomi yang tidak mendukung.

Padahal tingkat pendidikan seseorang sangat mempengaruhi dalam pembentukan pengetahuan dan sikap seseorang, termasuk remaja dalam hal ini pengetahuan dan sikap tentang seksual pranikah. Pendidikan yang tinggi diharapkan dapat membentuk pengetahuan yang tinggi dan selain itu juga diharapkan dapat membentuk sikap yang baik, dalam hal ini sikap remaja yang baik yaitu mengenai upaya-upaya pencegahan terjadinya seksual pranikah.

Tabel 4. Menunjukkan bahwa jumlah responden yang pernah mendapatkan informasi tentang pendidikan seksual yang diterima responden sebelumnya sebanyak 31 orang $(86,11 \%)$, dan jumlah responden yang tidak pernah mendapatkan informasi tentang pendidikan seksual sebanyak 5 orang $(13,89 \%)$. Dan dari hasil penelitian sumber informasi yang diperoleh responden paling banyak adalah melalui televisi sebanyak 26 responden $(72,22 \%)$, dan paling sedikit adalah dari petugas kesehatan sebanyak 1 responden $(2,78 \%)$. 
Hal ini dipengaruhi oleh banyaknya faktor sebagai dampak dari pengaruh informasi global dengan perkembangan teknologi yang semakin meningkat, sehingga remaja pada umumnya sudah memperoleh informasi melalui media elektronik yaitu televisi yang menyajikan informasi secara bebas dan terbuka tanpa diimbangi penjelasan yang lebih mendalam dan arahan secara positif, sehingga pengetahuan yang diperoleh remaja dapat disalah artikan dan kurang dapat dipahami dengan jelas dan benar, serta dapat menjadikan remaja menghadapi kebiasaan tidak sehat.

Pada tabel 5. Tingkat pengetahuan sebelum pemberian penyuluhan kesehatan reproduksi atau pretes (O1) sebagian responden mempunyai pegetahuan sedang yaitu sebanyak 19 orang $(52,78 \%)$ dan yang mempunyai pengetahuan tinggi sebanyak 14 orang $(38,89 \%)$ dan responden yang mempunyai pengetahuan rendah sebanyak 3 orang $(8,33 \%)$. Kemudian jika dibandingkan dengan tingkat pengetahuan responden setelah pemberian penyuluhan kesehatan reproduksi atau postes $(\mathrm{O} 2)$ maka jumlah responden yang mempunyai pengetahuan tinggi mengalami peningkatan yaitu sebanyak 32 orang $(88,89 \%)$.

Jumlah responden yang mempunyai pengetahuan sedang mengalami penurunan yaitu sebanyak 4 orang $(11,11 \%)$ dan tidak ada responden yang mempunyai pengetahuan rendah. Ini artinya terjadi peningkatan pengetahuan setelah diberikan penyuluhan kesehatan karena jumlah responden yang mempunyai pengetahuan tinggi meningkat sebesar $50 \%$ dan jumlah responden yang mempunyai pengetahuan sedang mengalami penurunan sebesar $41,67 \%$, dan tidak ada responden yang mempunyai pengetahuan rendah.

Dari hasil penelitian yang didapatkan mengenai pengetahuan setelah pemberian penyuluhan kesehatan reproduksi, hasil dari tingkat pengetahuan responden tentang kesehatan reproduksi menggambarkan kelompok responden sudah mempunyai pengetahuan yang baik.

Hal ini sesuai dengan yang dikemukakan Sarwono (2007), menyatakan pengetahuan seseorang dapat bertambah dengan diperolehnya informasi tentang obyek tertentu. Pengetahuan juga dapat diperoleh melalui pendidikan, media massa, maupun lingkungan. Pengetahuan diperlukan sebagai dorongan psikis dalam menumbuhkan rasa percaya diri maupun dorongan sikap dan perilaku (Notoatmodjo, 2007). Dalam penelitian ini peneliti menggunakan media berupa lembar balik dan leaflet agar dapat memudahkan responden untuk memahami makna dari penyuluhan yang disampaikan.

Pada tabel 6. Dapat dilihat sikap remaja sebelum pemberian penyuluhan kesehatan reproduksi atau pretes (O1) sebagian responden mempunyai sikap baik sebanyak 19 orang $(52,78 \%)$ dan sebagian responden mempunyai sikap cukup baik sebanyak 17 orang $(47,22 \%)$. Jika dibandingkan dengan sikap responden setelah pemberian penyuluhan kesehatan reproduksi atau postes $(\mathrm{O} 2)$ maka jumlah responden yang mempunyai sikap baik sebanyak 30 orang $(83,33 \%)$, dan responden yang mempunyai sikap cukup baik sebanyak 6 orang $(16,67 \%)$, dan tidak ada responden yang mempunyai sikap kurang baik.

Hal ini terlihat jelas berarti terjadi peningkatan jumlah responden yang mempunyai sikap baik tentang pendidikan seksual pranikah yaitu sebesar 30,56\% dan jumlah responden yang mempunyai sikap cukup baik mengalami penurunan sebesar 30,56\%. Ini berarti pemberian penyuluhan kesehatan reproduksi disamping dapat meningkatkan pengetahuan remaja tentang seksual pranikah juga dapat meningkatkan sikap remaja yang lebih baik mengenai seksual pranikah.

Pengetahuan seorang remaja diperoleh dari pengalaman berasal dari berbagai informasi, media massa, petugas kesehatan, orang tua, dan teman sebaya, 
akan berpengaruh terhadap sikap, dari sikap ini membentuk keyakinan sehingga seseorang dapat menentukan sikapnya. Dan hasil hubungan antara tahu dari input mengenai stimulus yang datang dari individu dalam hal ini pengetahuan merupakan suatu stimulus yang akhirnya akan membentuk suatu sikap yang baik. (Notoatmodjo, 2007)

Efektivitas penyuluhan kesehatan reproduksi terhadap pengetahuan dan sikap remaja tentang seksual pranikah. Berdasarkan pada tabel 7. Didapatkan data yaitu mempunyai perbedaan tingkat pengetahuan antara sebelum dan sesudah penyuluhan, terjadi peningkatan pengetahuan setelah diberikan penyuluhan.

Hasil uji statistik Paired t-test diketahui nilai $\mathrm{T}_{\text {hitung }}$ didapatkan $-19,648$ menunjukkan bahwa tingkat pengetahuan sebelum diberikan penyuluhan lebih kecil dari pada sesudah pemberian penyuluhan, dimana nilai $\mathrm{P}=0,000$ nilai tersebut lebih kecil dari alfa $(\mathrm{P}<0,05)$, artinya ada beda rata-rata antara nilai sebelum pemberian penyuluhan dengan sesudah pemberian penyuluhan kesehatan reproduksi tentang seksual pranikah.

Tabel 8. Didapatkan data yaitu mempunyai perbedaan sikap responden antara sebelum dan sesudah pemberian penyuluhan, terjadi peningkatan sikap setelah diberikan penyuluhan. Hasil $\mathrm{T}_{\text {hitung }}$ didapatkan $-9,564$ menunjukkan bahwa sikap responden sebelum diberikan penyuluhan lebih kecil dari pada sesudah pemberian penyuluhan, dimana nilai $\mathrm{P}=$ 0,000 nilai tersebut lebih kecil dari alfa $(\mathrm{P}<0,05)$, artinya ada beda rata-rata antara nilai sebelum pemberian penyuluhan dengan sesudah pemberian penyuluhan kesehatan reproduksi tentang seksual pranikah.

Berdasarkan analisa hasil yang diperoleh dalam penelitian ini berarti pemberian penyuluhan kesehatan reproduksi dapat meningkatkan pengetahuan dan sikap remaja mengenai seksual pranikah. Demikian juga dalam penelitian ini menunjukkan terdapat perbedaan antara sebelum pemberian penyuluhan kesehatan reproduksi dengan sesudah pemberian penyuluhan kesehatan reproduksi baik pengetahuan maupun sikap remaja tentang seksual pranikah yang menunjukkan bahwa semakin tinggi tingkat pengetahuan remaja tentang pendidikan seksual pranikah maka sikap remaja juga akan semakin baik terhadap upaya pencegahan terjadinya seksual pranikah yang banyak terjadi dikalangan remaja.

Dengan demikian terlihat jelas bahwa adanya efektivitas penyuluhan kesehatan reproduksi terhadap pengetahuan dan sikap remaja tentang seksual pranikah. Pentingnya informasi mengenai seksual pranikah pada remaja yang diberikan secara jelas dan benar yaitu salah satunya dengan pemberian penyuluhan kesehatan reproduksi tentang seksual pranikah dari petugas kesehatan, sehingga dapat meningkatkan pengetahuan dan sikap remaja menjadi lebih baik.

\section{Kesimpulan}

Dari penelitian ini dapat disimpulkan bahwa penyuluhan kesehatan reproduksi tentang seskual pranikah efektif secara sangat signifikan terhadap pengetahuan dan sikap remaja. Pada tingkat pengetahuan responden tentang kesehatan reproduksi mengenai seksual pranikah sebelum mendapatkan penyuluhan dengan tingkat pengetahuan tinggi sebesar 14 orang $(38,89 \%)$. Sesudah mendapatkan penyuluhan kesehatan reproduksi pengetahuan remaja rata-rata dalam kategori tingkat pengetahuan yang tinggi yaitu sebesar 32 orang $(88,89 \%)$.

Sedangkan pada sikap remaja tentang kesehatan reproduksi mengenai seksual pranikah sebelum mendapatkan penyuluhan dalam kategori sikap baik sebesar 19 orang (52,78\%). Dan sesudah mendapatkan penyuluhan kesehatan reproduksi sikap responden rata-rata dalam kategori sikap baik yaitu sebesar 30 orang $(83,33 \%)$. Dari hasil penelitian ini 
diharapkan memberikan informasi kepada remaja dalam peningkatan pengetahuan dan sikap remaja mengenai seksual pranikah, sehingga dengan informasi yang benar dan jelas, diharapkan remaja bisa lebih hati-hati dalam pergaulannya.

\section{Daftar Pustaka}

[1] Ali, M dan Asrori, M. (2006) Psikologi Remaja Perkembangan Peserta Didik. Jakarta : Bumi Aksara

[2] Arikunto, Suharsimi. (2006) Prosedur Penelitian Pendidikan Praktik. Jakarta : Rineka Cipta

[3] Azwar, Saifuddin. (2007) Sikap manusia teori dan pengukurannya. Yogyakarta : Pustaka Pelajar

[4] Deppartemen Kesehatan RI. 2004. Profil Kesehatan Indonesia Tahun 2004. Jakarta: Departemen Kesehatan.

[5] Hadi, Sutrisno. (2004) Metodologi Research. Yogyakarta : Andi.
[6] Manuaba, Ida Bagus Gde. (2005) Memahami kesehatan Reproduksi Wanita. Jakarta : Arcan

[7] Machfoedz, Ircham. (2005) Teknik Membuat Alat Ukur Penelitian Bidang Kesehatan, Keperawatan, dan Kebidanan. Yogyakarta : Fitramaya

[8] Machfoedz, Ircham. (2005) Pendidikan Kesehatan Bagian dari Promosi Kesehatan. Yogyakarta : FitramayaNotoatmojo, Soekidjo. (2007) Pendidikan dan Perilaku Kesehatan. Jakarta : Rineka Cipta

[9] Riwidikdo, Handoko. (2006) Statistik Kesehatan. Yogyakarta : Mitra Cendikia Press

[10] Setiadi. (2007) Konsep dan Penulisan Riset keperawatan. Yogyakarta : Graha Ilmu

[11] Sugiyono. (2006) Statistik Untuk Penelitian. Bandung : IKAPI

[12] Sarwono, Sarlito, W. (2006) Psikologi Remaja ed. Revisi. Jakarta : Raja Grafindo Persada 